Gut, 1960, 1, 242.

\title{
FACTORS INFLUENCING THE GROWTH OF STAPHYLOCOCCUS AUREUS IN THE STOMACH AFTER GASTRIC OPERATIONS
}

BY

\author{
F. G. SMIDDY and D. PRATT
}

From the University Department of Surgery, General Infirmary, Leeds

The frequency of post-operative staphylococcal invasion of the stomach appears to be related to the concentration of acid in the stomach. Evidence is presented suggesting that when it occurs such bacterial invasion may arise from the intestine rather than from the nose.

Acute entero-colitis as a complication of surgery was first recognized by Finney (1893) and somewhat later Riedel (1902) reported a personal series of five cases, describing the condition as a severe inflammatory process afflicting the bowel, characterized by the formation of a diphtheritic-like membrane on the wall of the gut from which Loeffler's bacillus could not be isolated. This acute intestinal inflammation develops most frequently between the third and second post-operative days, although occasional cases have been reported in which an interval as long as 39 days occurred between operation and the first manifestations of the disease. Many regard the condition as occurring primarily in the surgical patient, but Kleckner, Bargen, and Baggenstoss (1952) have also reported the syndrome in patients suffering from medical emergencies such as coronary thrombosis.

Normally the disease presents in one of two ways; either sudden torrential watery diarrhoea begins, the stools being likened to rice water, or alternatively vascular collapse occurs in a patient apparently convalescing normally after operation. It is this latter mode of presentation in patients who have undergone abdominal operations which leads to difficulties in diagnosis since many other causes of circulatory collapse exist in the early postoperative period.

When the disease became generally recognized there appeared to have been little doubt in the minds of those reporting these cases that the basic aetiological factor in this condition was an antibioticresistant Staphylococcus aureus. In more recent times, however, considerable doubt has been expressed as to the correctness of this hypothesis. Thus Dearing, Heilman, and Sauer (1954) stated that in the Mayo Clinic the incidence of postoperative entero-colitis had not risen following the introduction of antibiotics. Turnbull (1957) found that patients might die of fulminating staphylococcal lesions together with entero-colitis but from this latter lesion no staphylococci could be isolated even when using the most refined culture techniques. Weismann and Twitchell (1956) considered that the evidence in favour of the staphylococcus as the primary factor was weak and suggested that such pseudonyms as staphylococcal entero-colitis should not be used in the absence of concrete bacteriological and pathological evidence. With this view Kay, Richards, and Watson (1958) concur, and indeed these latter authors have separated the severe post-operative diarrhoeas into two groups: those in which the staphylococcus can be incriminated as the major cause of disease, i.e., staphylococcal enteritis, and a second group, acute necrotising entero-colitis either patchy or diffuse, in which this organism, in their opinion, cannot be held responsible for the pathological changes. They point out that the differentiation of these two conditions is of considerable clinical importance since staphylococcal enteritis is potentially reversible if it is recognized early and treated effectively, whereas necrotising entero-colitis is a grave disease resistant to treatment and having a high mortality.

It is commonly assumed that the environment presented to bacteria by the highly acid gastric contents is inimical to bacterial growth. Bacteriological examination of the small bowel by Cregan and Maynard (1953) also showed that the jejunum and greater part of the ileum were without resident flora and practically sterile; nevertheless in staphylococcal enteritis the organism gains entrance into 
the small bowel. There appears to be some doubt as to the route of infection. Brodie, Kerr, and Somerville (1956) found that faecal carriers of staphylococci were also nasal carriers and considered it likely that such organisms could ascend to the small bowel from the large as well as descend from the nasopharynx. Corridan and Shucksmith (1958) also considered that in their fatal case of post-operative enteritis in which staphylococci were cultured from the nasopharynx, stomach, and faeces, the route of infection had been from the colon.

It seems reasonable, however, to suppose that if staphylococci are present in the nasopharynx, an indwelling tube, such as is commonly used in the early post-operative treatment of the patient subjected to gastric surgery, might be the agent whereby the stomach, and thence the small bowel, becomes infected with this organism, particularly if the factors unfavourable to bacterial growth in the stomach have been removed or modified by the operation. The present investigation was designed to test this hypothesis. For this purpose the following information was secured on 44 consecutive patients admitted to the Professorial Surgical Unit: (a) The frequency with which staphylococci are present in the nasopharynx, $(b)$ the incidence of colonization of the gastric remnant by staphylococci within the first 48 hours after operation, (c) the relationship of bacterial growth in the post-operative stomach to variations in the $p \mathrm{H}$ of the gastric contents, and $(d)$ the occurrence of post-operative diarrhoea.

\section{MATERIALS AND MethodS}

The 44 patients were suffering from duodenal, gastric, or anastomotic ulceration, and the operations performed included resections of Polya or Billroth I type, or gastroenterostomy with or without vagotomy (Table I).

TABLE I

INDICATIONS FOR SURGERY AND OPERATION IN 50 CONSECUTIVE PATIENTS UNDERGOING GASTRIC OPERATIONS

\begin{tabular}{c|c|c|c|c}
\hline & \multicolumn{4}{|c|}{ Operation Performed } \\
\cline { 2 - 5 } $\begin{array}{c}\text { Indication for } \\
\text { Operation }\end{array}$ & $\begin{array}{c}\text { Polya } \\
\text { Resection }\end{array}$ & $\begin{array}{c}\text { Billroth I } \\
\text { Resection }\end{array}$ & $\begin{array}{c}\text { Posterior } \\
\text { Gastro- } \\
\text { enterostomy }\end{array}$ & $\begin{array}{c}\text { Posterior } \\
\text { Gastro- } \\
\text { enterostomy } \\
\text { and } \\
\text { Vagotomy }\end{array}$ \\
\hline $\begin{array}{c}\text { Duodenal ulcer } \\
\text { Prepyloric ulcer }\end{array}$ & 28 & 1 & 1 & - \\
$\begin{array}{c}\text { Gastric ulcer } \\
\text { Anastomotic } \\
\text { ulcer }\end{array}$ & 3 & 4 & - & - \\
\hline
\end{tabular}

After admission to the wards nasal swabs were taken and sent for bacteriological examination with specific requests for information regarding the Staphylococcus aureus and its antibiotic sensitivity if present. On the morning of the day of operation, normally 24 hours after admission, a No. $10 \mathrm{~F}$ oesophageal tube was passed, and at laparotomy this was adjusted so that the open internal end lay within 1 in. of the stoma. Following operation the stomach or gastric remnant was aspirated every hour for 48 hours and the $p \mathrm{H}$ of the samples obtained was determined using a Pye Weston moving coil $\mathrm{pH}$ meter. The presence or absence of bile was also noted at this time. At 24 and 48 hours after operation a sterile polythene catheter was passed down within the lumen of the oesophageal tube and a small quantity of the gastric contents aspirated. These specimens were examined for staphylococci by culture on an $8 \%$ sodium chloride nutrient agar medium as well as on fresh blood and chocolate agar media, the two latter containing $10 \%$ horse blood. If Staphylococcus aureus was cultured the antibiotic sensitivity of the organism was determined by the punch plate technique at concentrations of 2 and $20 \mu \mathrm{g}$. $/ \mathrm{ml}$. of a variety of antibiotics (Tables III and V).

\section{RESULTS}

BACTERIOLOGY OF THE NASOPHARYNX BEFORE OPERATION.-The nasal flora found pre-operatively in the patients of this series are shown in Table II.

TABLE II

BACTERIAL FLORA OF NASOPHARYNX IN 44 PATIENTS ABOUT TO UNDERGO GASTRIC OPERATIONS

\begin{tabular}{l|c}
\hline \multicolumn{1}{c|}{ Organism Isolated } & $\begin{array}{c}\text { No. of Cases in } \\
\text { which it was Grown }\end{array}$ \\
\hline Staph. aureus coagulase positive & 21 \\
Diphtheroids or staph. coagulase negative & 23 \\
Other commensals & 17 \\
\hline
\end{tabular}

From Table II it will be seen that in approximately $50 \%$ of all patients coagulase-positive staphylococci were isolated from nasal swabs. The sensitivity of these staphylococci to antibiotics is indicated in Table III, the isolated organism being insensitive in two-thirds of the cases to both penicillin and streptomycin. It will be noted further that in many of the cases the organisms were also resistant to aureomycin, and almost invariably they were sensitive to erythromycin. In two patients, however, the organism isolated was insensitive to the entire range of antibiotics listed in Table III.

TABLE III

ANTIBIOTIC SENSITIVITY OF COAGULASE-POSITIVE STAPHYLOCOCCI ISOLATED FROM NASOPHARYNX BEFORE OPERATION

\begin{tabular}{l|c|c|c}
\hline Antibiotic Tested & Sensitive & Insensitive & Unknown \\
\hline Penicillin & In 4 patients & In 16 patients & In 1 patient \\
Streptomycin & In 2 patients & In 18 patients & In 1 patient \\
Aureomycin & In 4 patients & In 13 patients & In 4 patients \\
Chloromycetin & In 2 2 patients & In 9 9 patients & In 10 patients \\
Terramycin & In 5 patients & In 15 patients & In 1 patient \\
Erythromycin & In 15 patients & In 3 patients & In 3 patients \\
Novobiocin & In 12 patients & In 4 patients & In 5 patients \\
\hline
\end{tabular}

Two coagulase-positive staphylococci were insensitive to all antibiotics in the above group. 
Bacteriology of Post-operative Stomach.-The bacterial flora on the first and second postoperative days are shown in Table IV. The

TABLE IV

BACTERIAL FLORA OF STOMACH IN 44 PATIENTS AFTER GASTRIC OPERATIONS

\begin{tabular}{|c|c|c|}
\hline \multirow{2}{*}{$\begin{array}{c}\underset{\text { Organism }}{\text { Grown }} \\
\text { from } \\
\text { Gastric Aspirate }\end{array}$} & \multicolumn{2}{|c|}{$\begin{array}{l}\text { No. of Cases in which Organism was } \\
\text { Isolated }\end{array}$} \\
\hline & $\begin{array}{c}\text { First } \\
\text { Post-operative Day }\end{array}$ & $\begin{array}{c}\text { Second } \\
\text { Post-operative Day }\end{array}$ \\
\hline $\begin{array}{l}\text { Staphylococcus } \\
\text { Coliform or proteus } \\
\text { Sterile }\end{array}$ & $\begin{array}{l}22 \\
12 \\
10\end{array}$ & $\begin{array}{l}11 \\
10 \\
23\end{array}$ \\
\hline
\end{tabular}

stomach was sterile in only 10 of the 44 patients at the end of the first 24-hour period. In the remainder, evidence of bacterial invasion was found. Thus in 22 patients a coagulase-positive staphylococcus was found at the end of 24 hours and even at the end of 48 hours positive cultures of this organism were obtained in 11 patients. Coliform organisms or $B$. proteus were isolated in 12 patients at $\mathbf{2 4}$ hours and at $\mathbf{4 8}$ hours the gastric contents in $\mathbf{1 0}$ of these cases still contained these organisms.

The sensitivity of the staphylococci isolated from the post-operative stomach is shown in Table $\mathrm{V}$. From this it will be seen that the majority of organisms were insensitive to all antibiotics other than erythromycin, as were the staphylococci isolated from the nasopharynx before the operation (Table II). The observation that staphylococci of similar sensitivity to antibiotics can be isolated from the post-operative stomach and from the nasopharynx before operation in an equal number of patients might suggest a close correlation between these two factors. On analysis, however, it was found that only nine of the 22 patients with positive staphylococcal nasal swabs developed positive gastric cultures for this organism at the end of the first post-operative day. In the other 13 patients in whom staphylococcal colonization occurred in the post-operative stomach at this stage, only commensals had been found in the nasopharynx.
pH of Contents of Post-operative Stomach.As regards the hydrogen ion concentration of the gastric contents during the $\mathbf{4 8}$ hours after operation, the cases have been divided into four groups according to the bacteriological state of the stomach as follows:-

Group 1.-Those patients in whom the stomach was sterile at both 24 and 48 hours after operation (10 patients).

Group 2.-Those in whom the stomach was colonized by coliform organisms or $B$. proteus at both 24 and 48 hours (12 patients).

Group 3.-Those patients in whom a coagulasepositive staphylococcus was present at 24 and 48 hours (11 patients).

Group 4.-Those in whom the staphylococcus was isolated at 24 hours but not at 48 hours (11 patients).

In order to simplify the presentation of results the $p \mathrm{H}$ value and presence or absence of bile in the gastric contents of each of these four groups of cases have been expressed not as an hourly determination, but as the findings on pooled hourly collections over six-hour periods. The results obtained are shown in graphic form in Fig. 1.

It will be seen that in Groups 2,3 , and 4 the hydrogen ion concentration of the gastric contents was low during the first 24-hour period as shown by $p H$ readings in the neighbourhood of 7 and 8 . Examination of the findings on individual patients confirmed these observations on the grouped cases. In Groups 2 and 3 the $p H$ values of the gastric contents remained high during the second 24 hours also, but in Group 4 there was a striking fall in the $p \mathrm{H}$ during this second day. In the patients of Group 1 the $p \mathrm{H}$ was significantly lower ( $p \mathrm{H} \mathrm{4 \cdot 0-5 \cdot 6)}$ during the first 24 hours than in the other three groups and this relatively greater gastric acidity continues in this group throughout the second 24 hours. The possible significance of this finding will be discussed below.

In the majority of patients bile was present within

TABLE V

SENSITIVITY TO VARIOUS ANTIBIOTICS OF COAGULASE-POSITIVE STAPHYLOCOCCUS AUREUS GROWN FROM POST-OPERATIVE STOMACH

\begin{tabular}{|c|c|c|c|c|c|c|}
\hline \multirow{3}{*}{ Antibiotic Used } & \multicolumn{6}{|c|}{ Sensitivity of Organisms } \\
\hline & \multicolumn{3}{|c|}{$\begin{array}{l}\text { First Post-operative Day } \\
22+\text { ve Cultures }\end{array}$} & \multicolumn{3}{|c|}{$\begin{array}{l}\text { Second Post-operative Day } \\
11+\text { ve Cultures }\end{array}$} \\
\hline & Sensitive & Insensitive & Unknown & Sensitive & Insensitive & Unknown \\
\hline $\begin{array}{l}\text { Penicillin } \\
\text { Streptomycin } \\
\text { Terramycin } \\
\text { Chloromycetin } \\
\text { Erythromycin } \\
\text { Novobiocin }\end{array}$ & $\begin{array}{r}4 \\
2 \\
3 \\
3 \\
12 \\
9\end{array}$ & $\begin{array}{r}18 \\
18 \\
17 \\
11 \\
2 \\
2\end{array}$ & $\begin{array}{r}0 \\
2 \\
2 \\
2 \\
8 \\
11\end{array}$ & $\begin{array}{l}1 \\
1 \\
0 \\
0 \\
7 \\
6\end{array}$ & $\begin{array}{r}9 \\
7 \\
10 \\
10 \\
2 \\
3\end{array}$ & $\begin{array}{l}1 \\
3 \\
1 \\
1 \\
2 \\
2\end{array}$ \\
\hline
\end{tabular}



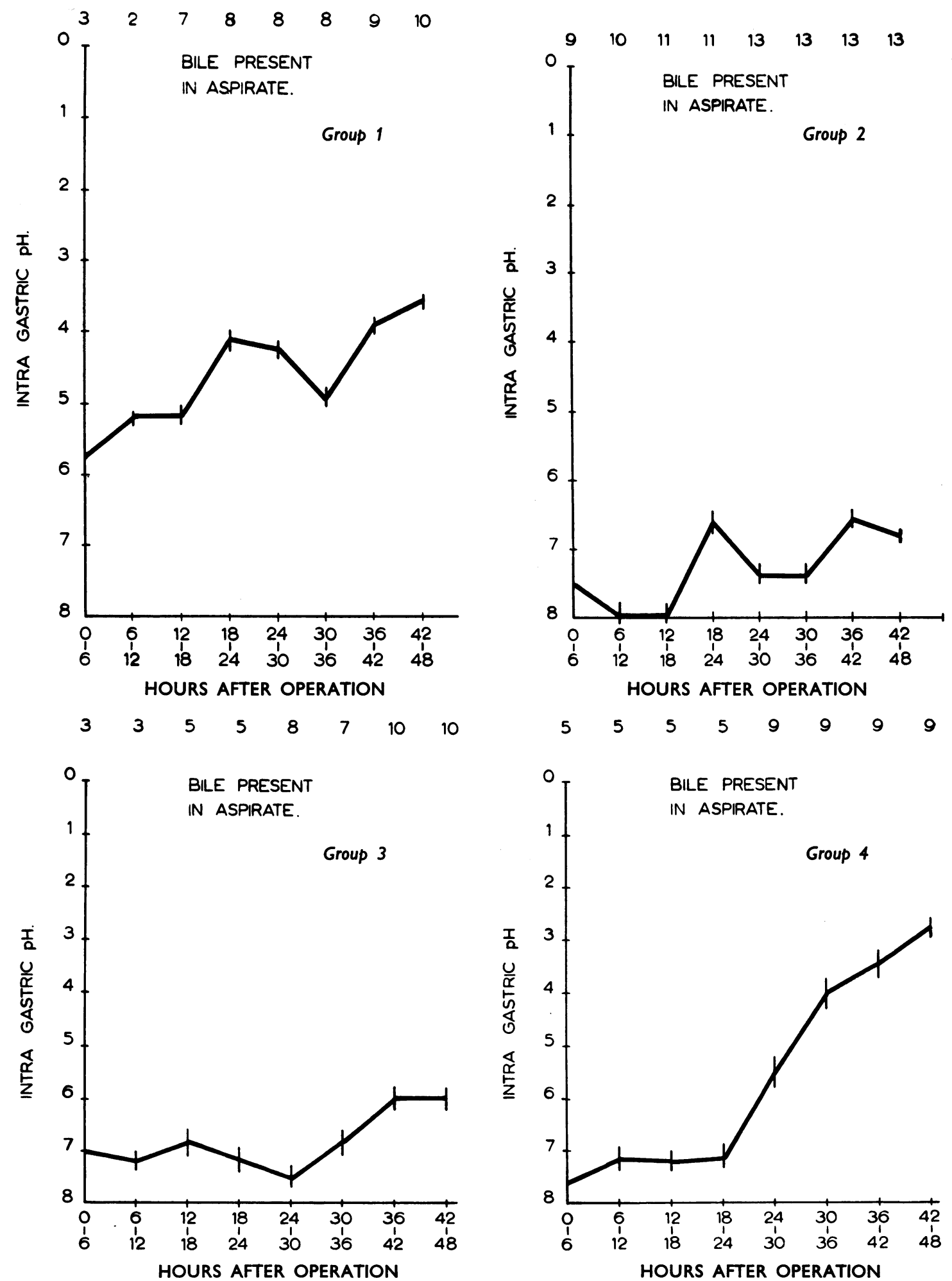

Fig. 1.-The $\mathrm{pH}$ value and presence or absence of bile in the aspirates from the stomach during the first 48 hours after operation: in 10 cases in which the gastric contents were found to be sterile at 24 and 48 hours (Group 1); in 12 cases in which coliform organisms were found in the gastric contents at 24 and 48 hours (Group 2); in 11 cases in which coagulase-positive staphylococci were present in the gastric contents at both 24 and 48 hours (Group 3); and in 11 cases in which coagulase-positive staphylococci were found in the gastric aspirate at 24 hours but not at 48 hours (Group 4). 
the remnant or stomach by the end of the first day, the frequency of bile-staining of aspirated contents being approximately equal in all four groups.

Development of Diarrhoea.-During the present study four patients had mild diarrhoea, seldom amounting to more than three or four motions a day. In each of the four the diarrhoea began during the fourth post-operative day, in one patient lasting for $\mathbf{2 4}$ hours, in two for $\mathbf{4 8}$ hours, and in the fourth patient for three days. After the passage of the first liquid motion the anus was swabbed and cultures of the next bowel action were made. A culture positive for Staphylococcus aureus was obtained in one patient. In none of the four patients was immediate or late treatment with erythromycin considered necessary and in all patients the diarrhoea terminated spontaneously.

\section{Discussion}

It is generally considered that the normal stomach is sterile except for a transient bacterial flora found soon after eating when the food contaminated by contact with the mouth infects the cavity. Sterility, however, may be lost in the presence of a malignant tumour or some alteration of mobility such as is found in pyloric stenosis (Oppler, 1895). In the small bowel, Cregan and Maynard (1953) found that the upper jejunum and midgut were also sterile, no growth occurring from 22 out of 28 samples taken from these sites at operation in patients with normal gastrointestinal tracts. In addition they found that in 12 out of 14 cultures taken from the lower ileum a mixed flora of such low growth intensity occurred that they regarded such bacteria as transient rather than resident. Thus there remain two potential bacterial reservoirs in man, the nose and mouth at the upper end, and, at the lower end, the colon.

There appear to be at least three mechanisms whereby the stomach and small bowel remain sterile in spite of the presence of these reservoirs of infection at either end of the alimentary tract. First, the gastric acidity: to initiate a growth of coliform or coagulase-positive staphylococci a $p \mathrm{H}$ of between 7.4 and 7.6 is required, but once initiated growth may proceed even in the presence of hydrogen ion concentrations as great as $p \mathbf{H ~ 4 \cdot 0 - 5 . 0 ~ ( W i l s o n ~}$ and Miles, 1955). Arnold and Brody (1926) also consider that the "auto-disinfecting" mechanism of the duodenum and jejunum is dependent upon acid derived from the stomach, since in this area the normal hydrogen ion concentration lies between 5.5 and 6.3 , a concentration dependent upon the delivery of acid-buffered material from the stomach.
Two further factors, however, are involved: first, the entrapping of bacteria by the lace-like network of mucus and, secondly, the onward passage of such mucus by normal peristaltic action which, in turn, diminishes retrograde infection of the lower ileum from the large bowel (Florey, 1933).

When a gastric operation is performed at least two of these normal mechanisms of "auto-disinfection" are disturbed. Since all gastric operations are designed to bring about a fall in acid secretion by one or more means, the level of acidity in various parts of the bowel changes with special emphasis on the alteration of the intragastric hydrogen ion concentration. The evidence produced here shows that without exception depression of acid secretion is constantly present on the first post-operative day. In some patients high hydrogen ion concentrations reappear on the second day. Later during convalescence free acid, i.e., $p \mathrm{H}$ greater than 3.5 , is found in the majority of patients (Smiddy, 1957). This lowering of the intragastric acidity, together with its effect on the intestinal acidity, appears, from the data presented, to be the factor determining bacterial invasion of the stomach or gastric remnant following operation. In those patients in whom an intragastric acidity of between 6.5 and 8.5 was found coliform or coagulase-positive staphylococci were isolated from gastric aspirates. In those in whom a higher hydrogen ion concentration was present, $p \mathrm{H}$ range $5 \cdot 5-3 \cdot 5$, the stomach remained sterile, and in those in whom staphylococci were present on the first day a marked rise in intragastric acidity appeared to sterilize the remnant during the second post-operative day. The presence or absence of bile in the stomach does not seem to bear any relation to bacterial invasion.

Although this evidence allows one to assume then that the stomach in some $50 \%$ of patients will be colonized by staphylococci within 24 hours of a gastric operation, it does not answer the question as to the source of infection. Two alternative routes of infection are possible, downwards from the nose, or upwards from the bowel. The finding that, in keeping with the nasal carrier rate of Staphylococcus aureus in the general population, approximately $50 \%$ of patients in this series had positive nasal swabs soon after admission is consistent with a descending route of infection, since from $50 \%$ of patients staphylococci can be grown from the stomach within 24 hours of operation. This hypothesis is supported by the almost identical sensitivity and resistance patterns of the staphylococci isolated but seems to be rendered completely invalid by the fact that in more than half the patients in whom staphylococci were isolated from gastric aspirates, no staphylococci were present 
pre-operatively in the nose. Furthermore, the presence of coliform organisms in the stomach remnant cannot be explained in terms of downward spread of bacteria from the nasopharynx. It would appear reasonable to assume that the gastric invasion with the coliform group occurred by retrograde spread from the lower bowel and it is, therefore, not unlikely that staphylococci ascended by this route also. There can be no doubt that conditions in the bowel post-operatively would favour retrograde spread. First, intraluminal acidity is altered in favour of bacterial growth and secondly, intestinal peristalsis is diminished, thus removing the factor of onward passage of entrapped bacteria in the mucus lacework. To substantiate this hypothesis of retrograde infection it would be necessary to phage-type the nasal, intragastric, and colonic staphylococci isolated; this unfortunately was not done in this study.

Has this staphylococcal colonization of the postoperative stomach any significance in regard to the development of pseudo-membranous entero- colitis? The fact that none of the patients studied in this enquiry, and particularly none of those in the group with staphylococci in the gastric contents postoperatively, developed typical entero-colitis, certainly seems to belittle the importance of gastric infection of this kind in the aetiology of this complication. It has also to be remembered that in ordinary surgical practice many of the patients who develop entero-colitis have not had a gastric operation and presumably retain normal conditions of acidity in the stomach which are inimical to the growth of organisms there.

One further point deserves comment. The high incidence of resistance of both nasal and gastric staphylococci isolated in this series to all antibiotics other than erythromycin reinforces the argument that the "prophylactic" use of penicillin and streptomycin in the early post-operative phase should be abandoned and that infections developing during the course of convalescence should be treated with antibiotics appropriate to the predetermined sensitivity of the organism.

\section{CONCLUSION}

It has been shown that $50 \%$ of a group of patients admitted for gastric operations harbour Staphylococcus aureus in the nose immediately after entry to hospital, and that many of these organisms are highly resistant to the commonly used antibiotics, penicillin and streptomycin. In some $50 \%$ of this same group of patients strains of Staphylococcus were isolated from the stomach contents 24 hours after operation, but it was usually patients who had had negative pre-operative nasopharyngeal swabs who developed such gastric infestation. The frequency of post-operative staphylococcal invasion of the stomach appears to be related to the intragastric hydrogen ion concentration, since in-patients in whom a relatively high degree of acid secretion returns during the second post-operative day the gastric contents are invariably found to be sterile. The frequent presence of coliform organisms in the post-operative stomach, along with staphylococci, suggests that the bacterial invasion of the stomach is from the intestine rather than from the nose.

I wish to thank Doctors G. M. Williamson, A. T. Willis, and S. Jacobson for their bacteriological contributions to this work, Professor J. C. Goligher and Dr. K. S. Zinnemann for their help in the preparation of this manuscript, and Sisters J. Womersley and D. Lynas for their help in obtaining the specimens investigated. I am also grateful to S. Dove for the illustrations.

\section{REFERENCES}

Arnold, L. and Brody, L. (1926). Amer. J. Hyg., 6, 672.

Brodie, J., Kerr, M. R., and Somerville, T. (1956). Lancet, 1, 19. Corridan, M., and Shucksmith, H. S. (1958). Brit. J. Surg., 45, 361.

Cregan, J., and Maynard, N. J. (1953). Brit. med. J., 1, 1356.

Dearing, W. H., Heilman, F. R., and Sauer, W. G. (1954). Gastroenterology, 26, 38.

Finney, J. M. T. (1893). Johns Hopk. Hosp. Bull., 4, 53.

Florey, H. W. (1933). J. Path. Bact., 37, 283.

Kay, A. W., Richards, R. L., and Watson, A. J. (1958). Brit. J. Surg., 46, 45 .

Kleckner, H. S., Bargen, J. A., and Baggenstoss, A. H. (1952). Gastroenterology, $21,212$.

Oppler, B. (1895). Dtsch. med. Wschr., 21, 73.

Riedel, J. (1902). Dtsch. Z. Chir., 67, 402.

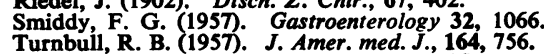

Weismann, R. E., and Twitchell, E. B. (1956). Ann. Surg., 144, 32.

Wilson, G. S., and Miles, A. A. (1955). Topley and Wilson's Principles of Bacteriology and Immunity, Vol. 1, 4th ed. Edward Arnold, London. 